\title{
RNA Vaccines in Cancer Treatment
}

\section{Anita Bringmann, Stefanie Andrea Erika Held, Annkristin Heine, and Peter Brossart}

\author{
Department of Oncology and Hematology, University Hospital Bonn, 53111 Bonn, Germany
}

Correspondence should be addressed to Peter Brossart, peter.brossart@ukb.uni-bonn.de

Received 23 December 2009; Accepted 22 March 2010

Academic Editor: Hanchun Yang

Copyright ( 12010 Anita Bringmann et al. This is an open access article distributed under the Creative Commons Attribution License, which permits unrestricted use, distribution, and reproduction in any medium, provided the original work is properly cited.

\begin{abstract}
The Cancer Report from the World Health Organization states that in the year $200012 \%$ of all death cases worldwide were caused by cancer. In the western world, the cancer death rates are often devastating, being at about $25 \%$. This fact stresses the urgency to find effective cures against malignant diseases. New approaches in the treatment of cancer focus on the development of immunotherapies to fight the disease. Besides other methods, the usage of tumor-specific RNA as part of vaccines is investigated lately. RNA, administered alone or used for transfection of dendritic cells, shows several advantages as a vaccine including feasibility, applicability, safeness, and effectiveness when it comes to the generation of immune responses. This review concentrates on results from in vitro experiments and recent trials using RNA vaccines to present an overview about this specific strategy.
\end{abstract}

\section{Introduction}

The diverse causes for cancer malignancies suggest that the therapy of patients should be individualized to offer an effective treatment for each person. Additionally, it is the goal to intervene at the molecular level and manipulate cells and ongoing processes to fight disease. For quite some time, the idea of using the own body's immune system for the treatment of cancer has been fascinating for its apparent simplicity and probable effectiveness. Due to this, studies on the topic have been going on since the 1970s [1-3]. At this time point first ideas to employ RNA for the generation of immune responses occurred and the term immunotherapy emerged. So-called immune RNA was extracted from lymphoid tissues of animals immunized with tumor cells and injected into patients as adjuvants $[1,2]$.

As easy as the idea sounds, however, researchers have been challenged with the complexity of the immune system and the generation of specific and effective immune responses against desired targets. One issue, that makes things both easier and more difficult, is the origin of cancer, which is altered self. It is easier, because tumor cells exhibit distinct differences in comparison to nonaltered body cells. Difficult, because, for one, these cells are still self cells and, second, they apply diverse mechanisms to evade recognition by the immune system.
Nevertheless, diverse approaches have been taken to use the differences between normal and tumor cells to teach the immune system to recognize malignancies and eliminate them. The goal in the generation of immunotherapeutic vaccines is the induction and perpetuation of a tumor specific immune response. As a consequence the body should be cleared from tumor cells, and additionally, the immune system should prevent the recurrence of the tumor. Therefore it is necessary to generate a complete immune response and to activate several leukocyte populations like antigenpresenting cells, CD4+ and CD8+ T cells and B cells. This will lead to the generation of memory cells, which have a protective function after the clearance of tumor cells.

One focus of current research is the usage of messenger RNA (mRNA) in diverse forms as a vaccine. In these approaches mRNA encoding for tumor-associated antigens or whole tumor cell RNA is applied to induce specific CTL responses $[4,5]$. Proceedings in experimental research and recent trials are the topic of this review.

\section{Tumor-Associated Antigens (TAAs)}

An important step for vaccine development has been and still is the identification of tumor-associated antigens (TAAs) [6]. As immune responses shall be induced, it is necessary 
to find immunogenic molecules, which are upregulated or best exclusively expressed in cancerous tissues but not or only lightly in healthy adult tissues.

Many TAAs are shared by tumor and normal tissues but are indeed overexpressed in tumor cells. The use of these broadly distributed antigens should be evaluated carefully, as they induce tolerance due to the negative selection processes during $\mathrm{T}$ cell development. If tolerance can be overcome, the generation of immune responses against these antigens might lead to the induction of autoimmune diseases. A subgroup of shared TAAs are differentiation antigens. They are not ubiquitously expressed, but specific for certain tumors and the tissues these tumors derived from. An example for differentiation antigens is Melan-A/MART-1 [7], which is almost solely expressed in melanoma cells and melanocytes. Although the distribution of differentiation antigens is restricted to certain tissues, the induction of tolerance towards these antigens still poses a problem. And again, it might be possible to create autoimmune effects when interfering with these TAAs.

A safer way to utilize the immune system would be the induction of immune responses against antigens that are uniquely expressed in tumor tissues. Two types of TAAs are indeed specific for tumor cells. Cancer/testis (CT) antigens [8] are expressed in several tumor tissues and in the germline but cannot be found in somatic tissues. CT antigens are not presented in the germline as MHC class I and class II molecules get not expressed at site. This means that the antigens will only be recognized in the tumor. In opposition to shared tumor antigens, the generation of immune responses will not lead to autoimmunity. An example for CT antigens is NY-ESO-1 [9], which already has been used as a target in immunotherapeutic approaches. Mutation antigens are also exclusively expressed in tumor tissues. Cancer cells often acquire several mutations, which lead to the translation of altered proteins. If mutations occur in oncogenes or tumor suppressor genes, this will induce the invasiveness of the malign tumor. Mutation antigens are suited perfectly for immunotherapy as these TAAs are not considered as self by the immune system and no tolerance has been induced towards them. Examples for mutation antigens are CDK4 [10], Kras [11], caspase8 [12], or TGF- $\beta$ receptor [13-15]. Another group of tumor-specific antigens are TAAs of viral origin. Several viruses, like HTLV-1, HIV, and EBV, induce the generation of tumor cells. Particularly, the development of non-Hodgkin lymphomas (NHL) and multiple myelomas $(\mathrm{MM})$ is associated with former viral infection. The altered cells present viral antigens on their surface, which can be the starting point for vaccine generation. In NHL and MM disease, the idiotype of the immunoglobulin can be targeted as well.

So far, depending on the type of disease, several useful TAAs have been identified. For melanoma patients, MART1/Melan A [7], gp100 [16], and tyrosinase [17, 18] seem to be promising targets. The TAAs Survivin [19-21] and MUC$1[22,23]$ are expressed in a broad variety of epithelial and haematological malignancies. CEA [24] is associated with pancreatic, colorectal, or gastric cancer, while MAGE-A [6] and NY-ESO-1 [9] are cancer testis antigens. Adipophilin
[25, 26], MMP-7 [27], RGS1 [28], and RGS5 [25, 29] have recently been identified as renal cell carcinoma TAAs. Examples for leukemia-associated antigens are Wilms' tumor protein (WT1) [30], proteinase $3[31,32]$, receptor for hyaluronan acid-mediated motility (RHAMM) [33], and Bax inhibitor-1 [34].

\section{Vaccine Delivery}

Having found specific differences between tumor and healthy tissue, the next challenge is to teach the immune system to perceive them. This is obviously done by administering the TAAs to the body. The question is still: How is it done in the best way?

Important issues to consider are the type of antigen, which should be applied, and the way the antigens should be delivered. When it comes to the type of antigen, diverse approaches have been taken. Peptides from TAAs or whole proteins have been used, whole cell tumor lysates or irradiated, apoptotic tumor cell bodies have been applied, and TAA-encoding plasmids or TAA/ whole tumor cell RNA were to try out. Besides the choice of the antigen the strategy of antigen delivery must be optimized. The above stated tumor antigens could be used as vaccines alone or together with additives like GM-CSF, IFN- $\alpha$, or IL-12. Instead of using the antigens as direct vaccines, they can also be brought into the body by dendritic cells. This review will focus on the use of RNA either alone or in combination with dendritic cells as a cancer vaccine. An overview over both methods is given in Figure 1.

\section{Dendritic Cells}

In the development of vaccines against cancer, many research groups focus on the usage of dendritic cells (DCs). DCs are, besides $\mathrm{B}$ cells and macrophages, antigen presenting cells (APCs) and are seen as the most potent population executing this function.

In their immature state, DCs mostly reside in tissues and in part travel through the blood and lymph streams. They express major histocompatibility complex (MHC) class II molecules, but only few costimulatory molecules like CD80 (B7.1) or CD86 (B7.2). While migrating through the body's periphery, DCs eventually encounter antigens. The cells incorporate these antigens through a variety of processes, namely, receptor-mediated endocytosis, phagocytosis, or macropinocytosis. After antigen ingestion, DCs migrate towards afferent lymphoid organs and differentiate into mature cells. During the maturation process DCs undergo several phenotypic and functional changes. They upregulate the expression of MHC class I and II molecules [35], the costimulatory molecules CD80, CD86 [36], and CD40 [37], as well as the adhesion molecules CD54 (ICAM-1), CD102 (ICAM-2), CD11a (LFA-1), CD58 (LFA-3), and CD209 (DCSIGN) [38-40]. As another prominent change, mature DCs increase the secretion of cytokines (IL-6, IL-12, IL-23, TNF$\alpha)$ and chemokines like CCL18 (DC-CK-1), which draws naïe $\mathrm{T}$ cells to the location. 
(A)

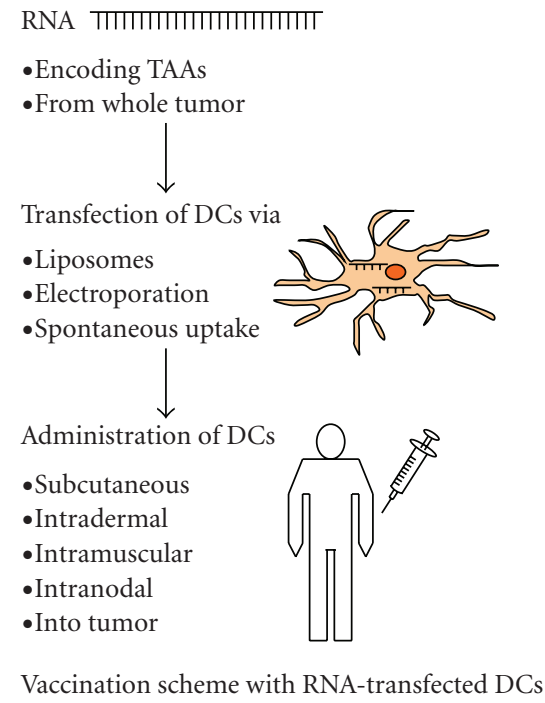

(B)

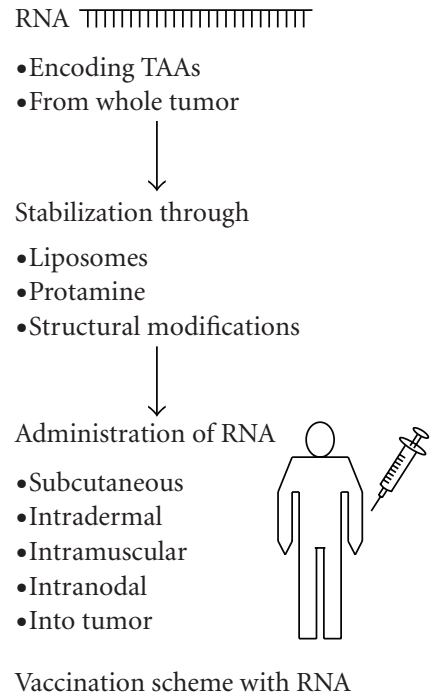

Figure 1: Overview over RNA-vaccination schemes using DCs (A) or pure/stabilized RNA.

Through their matching adhesion molecules, DCs and residing $\mathrm{T}$ cells interact with each other, forming immunological synapses. As a consequence, DCs present the processed antigens to T cells, these get activated, and antigenspecific responses are generated.

Depending on the nature of the antigen, either MHC class I or class II molecules are involved in their presentation. Like almost all cells of the body, DCs have the ability to present antigens via MHC class I molecules. This route is taken when antigens are of endogenous origin. After proteasomal degradation in the cytosol, generated peptides are transported into the ER, loaded onto MHC class I molecules, and brought to the cell's surface. There, the MHC class I molecules interact with $\mathrm{T}$ cell receptors from CD8 positive cytotoxic $\mathrm{T}$ lymphocytes (CTLs).

DCs can present exogenous antigens over MHC class II molecules. After incorporation, the antigens are degraded in endosomal-lysosomal compartments by cathepsins. Generated peptides are loaded onto MHC class II molecules, which interact with $\mathrm{CD} 4$ positive $\mathrm{T}$ cells.

Besides following the "classical" pathways of antigen processing and presentation, DCs are able to present exogenous antigens through MHC class I molecules. Engulfed antigens are transferred from lysosomal compartments into the cytosol and then follow the MHC class I pathway of processing and presentation. Through this so-called crosspriming, effective CTL responses can be generated [41-43].

\section{In Vitro Generation of Dendritic Cells}

The employment of DCs in vaccination strategies requires large amounts of this cell type. Until now, several protocols have been established for the generation of high quantities in vitro. DCs can be generated from CD34 positive precursors from bone marrow or blood, when the cells are incubated with cytokine cocktails containing granulocyte-macrophage colony stimulating factor (GM-CSF), IL-4, or TNF- $\alpha$ [4446]. A different approach uses CD14 positive monocytes from blood and the cytokines GM-CSF and IL-4 or CD40 ligand to generate myeloid DCs [47-49]. These cells are immature and express few costimulatory molecules on their surface but can be matured with different inflammatory stimuli like Toll-like receptor ligands, TNF- $\alpha$, or a mixture of compounds containing PGE 2 , TNF- $\alpha$, IL- $1 \beta$, and IL-6 [50].

\section{Usage of RNA}

RNAs, ribonucleic acids, are single-stranded polymers in their primary structure, containing the four nucleotides adenosine, guanosine, cytidine, and uridine monophosphate. These are linked through the $3^{\prime}$ and $5^{\prime}$ phosphate residues of the ribose sugars. In immunotherapy, messenger RNA (mRNA) is used, which contains the genetic information for proteins. The structure of processed and spliced mRNA has five structural features: A Cap structure, which is a 7-methylguanosine triphosphate, the $5^{\prime}$-untranslated region (UTR), the open reading frame (ORF) beginning with the start codon at the $5^{\prime}$ end and ending with the stop codon at the $3^{\prime}$ end, the $3^{\prime}$-UTR, and a poly A-tail at the $3^{\prime}$ end containing 100-250 residues.

In the first vaccination approaches, mRNA was extracted from autologous tumor tissues from patients. This procedure had the disadvantage that sufficient amounts of tumor cells had to be available. Nowadays it is possible to prepare high amounts of RNA in vitro. From few tumor cells one can extract RNA and generate complete tumor cDNA libraries to obtain the necessary amounts of RNA encoding multiple patient specific TAAs in the needed quality $[51,52]$. Besides the easy access to large quantities, the application of mRNA provides several advantages as a vaccine. RNA molecules are considered to be safe vaccines, as they are easily degraded. They are cleared quickly out of the organism and cannot, 
as opposed to plasmid DNA, integrate into the genome and influence the cell's gene expression in an uncontrollable manner [53]. Due to the stated facts, it is also unlikely that RNA vaccination causes severe side effects like the generation of autoimmune disease or anti-DNA antibodies. As a plus, the application of mRNA is, unlike peptide-based vaccinations, not MHC-restricted. An immune response against a broad variety of antigens can be generated and CD8 positive CTLs as well as CD4 positive T helper cells can get induced. A polyclonal immune response makes tumor escape less likely. Although the expression of genes cannot be regulated when RNA is used, this is eventually not necessary due to the molecule's instability. Unlike DNA, which has to be transfected into the nucleus, the transfection with RNA requires only insertion into the cell's cytoplasm, which is easier to achieve. All these issues speak for the utilization of RNA-based vaccines.

\section{RNA-Pulsed DCs as Vaccines}

One basic approach in RNA vaccination is the use of in vitro generated DCs as tumor antigen-presenting cells. Generated DCs can be transfected with RNA encoding single or multiple TAAs or whole tumor cell RNA. After transfection, the genetic information introduced into the DCs is translated into protein. These proteins underlie intracellular degradation processes and the generated peptides are presented on MHC class I and class II molecules.

Several in vitro experiments showed that DCs pulsed with whole tumor RNA or RNA encoding specific TAAs induce the generation of specific CTLs. This procedure was first described by the group of Gilboa and formed the basis for ongoing experiments [54]. Milazzo et al. electroporated monocyte-derived DCs with whole RNA from LP-1 and U266 cell lines and induced specific CTLs that lysed LP1 and U266 myeloma cells [55]. In different experiments, scientists used RNA from tumor-bearing patients instead of cell lines to generate CTL responses. Heiser et al. transfected DCs with RNA isolated from renal tumor cells [56]. The group showed the generation of polyclonal CTL responses and subsequent lysis of primary and metastatic tumor cells. Apparently, the polyclonal T cell activities were more potent than the CTL responses generated against a single antigen. However, in other settings the potency of immune responses induced by single TAAs was investigated. Nair et al. transfected DCs with CEA mRNA and stimulated specific CTL responses in vitro [24]. Grunebach et al. analyzed the influence of cotransfection of two different TAAs and electroporated DCs with Her-2/neu and 4-1BBL RNA. They found that costimulatory molecules were upregulated and immune responses were increased in comparison to single TAA transfection. Both CD8 and CD4 T cell responses were induced [57].

The transfection of DCs with RNA already leads to the initiation of the maturation process. It is still questioned if these stimuli are enough or if additional signals lead to more capable cells. Several additional maturation stimuli have been analyzed on the effect on DC phenotype and effectiveness on $\mathrm{T}$ cell proliferation and thus the generation of specific immune responses. Onaitis et al. transfected DCs with mRNA encoding Mart-1 and partly matured the cells with CD40 ligand [58]. An enhanced T-cell proliferation was found in the preparations with CD40L stimuli, which was due to the increased IL-12 secretion by the treated DCs. The same group discovered that the sequential stimulation with a cytokine cocktail (TNF- $\alpha$, IL-1 $\beta$, IL-6, and PGE $_{2}$ ) followed by incubation with CD40L enhances the generation of Mart-1-specific $\mathrm{T}$ cells, an effect again mediated by increased IL-12 production [59]. They also described the effective maturation of DCs by diverse Toll-like receptor ligands $[60,61]$. In mouse experiments the generation and further enhancement of $\mathrm{T}$ cell responses has been analyzed. Boczkowski et al. induced OVA-specific CTLs and protection from OVA-expressing tumors in mice [54]. Naka et al. cotransfected mouse DCs with tumor RNA as well as GMCSF RNA and used the cells as a vaccine [62]. The animals had already received immunotherapeutic treatment in a previous experiment and the re-growing of the tumor should be inhibited. The co-transfected DCs successfully induced augmented CTL responses and suppressed tumor growth. Kim et al. investigated whether it is possible to enhance immune responses against the antigen CEA when the TAA is modified. The group generated a fusion gene containing a truncated CEA $(\triangle \mathrm{CEA})$ devoid of its signal sequences, calreticulin (CRT), and the HIV TAT protein transduction domain (TAT-PTD) and pulsed DCs with the according RNA. The vaccine enhanced CEA-specific CD4 and CD8 responses and inhibited tumor growth and led to a prolonged survival of treated mice [63].

The promising results from in vitro experiments and studies in mice led to several human trials where patients with different malignancies were vaccinated with RNA transfected DCs (see Table 1).

Heiser et al. conducted a study on metastatic prostate cancer [64]. Sixteen patients were initially enrolled in the phase I trial and 13 followed the immunization schedule with PSA RNA-transfected DCs. The patients received 3 intravenous vaccination cycles with escalating doses of DCs, namely $1 \times 10^{7}$ cells (low dose), $3 \times 10^{7}$ cells (medium dose), and $5 \times 10^{7}$ cells (high dose), together with, $1 \times$ $10^{7}$ DCs intradermally administered at weeks 2,4 , and 6. The evaluation of specific $\mathrm{T}$ cell responses was carried out via ELISPOT and $\left[{ }^{51} \mathrm{Cr}\right]$-chromium-release assays. All nine patients that were analyzed showed PSA-specific CTL responses. Additionally, a decrease in the log slope PSA was detected in six of seven patients and three patients transiently showed clearance of circulating tumor cells. No severe adverse effects were observed after the vaccinations, stating the safety of this type of vaccine.

CEA is an important tumor marker expressed in colorectal, pancreatic, and gastric carcinomas as well as in the majority of breast and nonsmall cell lung cancers. The TAA has been object of recent phase I/II studies to evaluate its use in vaccination therapy. Immunizations with CEA mRNAtransfected DCs were administered to three patients with resected pancreatic adenocarcinoma [65]. The injections were given monthly for a time period of six months and the treated patients showed no recurrence of disease in the more 
TABLE 1: Recent clinical trials using RNA-transfected DCs.

\begin{tabular}{|c|c|c|c|c|c|c|}
\hline Cancer type & RNA source/target & Vaccination schedule & $\begin{array}{c}\text { Number of } \\
\text { study subjects }\end{array}$ & $\begin{array}{l}\text { Immunological } \\
\text { response }\end{array}$ & $\begin{array}{l}\text { Clinical } \\
\text { response }\end{array}$ & Reference \\
\hline $\begin{array}{l}\text { Colorectal } \\
\text { cancer }\end{array}$ & $\begin{array}{l}\text { Total autologous } \\
\text { tumor }\end{array}$ & $\begin{array}{l}10^{6} \text { DCs pulsed with } 25 \mu \mathrm{g} \text { RNA and KLH } \\
\text { intravenously } 4 \text { times on monthly } \\
\text { intervals. }\end{array}$ & 15 & NA & NA & {$[73]$} \\
\hline $\begin{array}{l}\text { Adenocar- } \\
\text { cinoma } \\
\text { (lung) }\end{array}$ & $\begin{array}{l}\text { Total autologous } \\
\text { tumor }\end{array}$ & $\begin{array}{l}3 \times 10^{7} \text { DCs transfected with } 300 \mu \mathrm{g} \text { RNA } \\
\text { intravenously, followed by } 10^{6} \mathrm{DCs} \\
\text { transfected with } 10 \mu \mathrm{g} \text { RNA intradermally } \\
4 \text { times on monthly intervals. }\end{array}$ & 1 & $1 / 1$ & NA & {$[93]$} \\
\hline $\begin{array}{l}\text { Pancreatic } \\
\text { cancer }\end{array}$ & CEA & $\begin{array}{l}10^{7} \text { DCs transfected with } 20 \mu \mathrm{g} \text { RNA } \\
\text { intradermally } 6 \text { times on monthly } \\
\text { intervals. }\end{array}$ & 3 & NA & NA & {$[65]$} \\
\hline Prostate & PSA & $\begin{array}{l}10^{7}-5 \times 10^{7} \text { DCs transfected with } 1.5 \mu \mathrm{g} \\
\text { RNA } 10^{6} \text { DCs intravenously, } 3 \text { times } \\
\text { biweekly with escalating dose and } 10^{7} \\
\text { DCs intradermally. }\end{array}$ & 16 & $9 / 9$ & NA & {$[64]$} \\
\hline $\begin{array}{l}\text { CEA- } \\
\text { expressing } \\
\text { cancers }\end{array}$ & CEA & $\begin{array}{l}10^{7}-10^{8} \text { DCs transfected with } 2 \mu \mathrm{g} \\
\text { RNA } / 10^{6} \text { DCs intravenously and } 0-10^{6} \\
\text { trasnfected DCs intradermally } 4 \text { times } \\
\text { biweekly. }\end{array}$ & 42 & NA & NA & {$[94]$} \\
\hline RCC & $\begin{array}{l}\text { Total autologous } \\
\text { tumor }\end{array}$ & $\begin{array}{l}10^{7}-5 \times 10^{7} \text { DCs transfected with } 50 \mu \mathrm{g} \\
\text { RNA } / 10^{7} \text { DCs intravenously, } 3 \text { times } \\
\text { biweekly with escalating dose and } 10^{7} \\
\text { DCs intradermally. }\end{array}$ & 15 & $6 / 7$ & NA & {$[72]$} \\
\hline Brain cancer & $\begin{array}{l}\text { Total autologous } \\
\text { tumor }\end{array}$ & $\begin{array}{l}0.5-5 \times 10^{7} \mathrm{DCs} / \mathrm{m}^{2} \text { transfected with } 5 \mu \mathrm{g} \\
\text { RNA/ } 10^{6} \mathrm{DCs} \text { intravenously and } 0.5 \times \\
10^{7} \mathrm{DCs} / \mathrm{m}^{2} \text { intradermally, } 3 \text { times } \\
\text { biweekly with escalating dose, } 3 \text { times at } \\
3 \text {-month intervals. }\end{array}$ & 9 & NA & $2 / 7 \mathrm{SD}$ & {$[95]$} \\
\hline $\begin{array}{l}\text { Neuroblas- } \\
\text { toma }\end{array}$ & $\begin{array}{l}\text { Total autologous } \\
\text { tumor }\end{array}$ & $\begin{array}{l}0.5-5 \times 10^{7} \mathrm{DCs} / \mathrm{m}^{2} \text { transfected with } 5 \mu \mathrm{g} \\
\text { RNA } / 10^{6} \mathrm{DCs} \text { intravenously and } 0.5 \times \\
10^{7} \mathrm{DCs} / \mathrm{m}^{2} \text { intradermally, } 3 \text { times } \\
\text { biweekly with excalating dose, } 3 \text { times at } \\
\text { 3-month intervals. }\end{array}$ & 11 & NA & $1 / 7 \mathrm{SD}$ & {$[96]$} \\
\hline RCC, OVA & $\begin{array}{l}\text { Total tumor from } \\
\text { clear cell carcinoma } \\
\text { tissue }\end{array}$ & $\begin{array}{l}\text { Arm 1: } 10^{7} \text { DCs electroporated with } 5 \mu \mathrm{g} \\
\text { RNA } / 10^{6} \text { DCs intradermally, } 3 \text { times } \\
\text { biweekly, } 18 \mu \mathrm{g} / \mathrm{kg} \mathrm{DAB} \text { DAg }_{389} \text { IL-2 prior to } \\
\text { vaccination. } \\
\text { Arm } 2: 10^{7} \text { DCs electroporated with } 5 \mu \mathrm{g} \\
\text { RNA } / 10^{6} \text { DCs intradermally, } 3 \text { times } \\
\text { biweekly. }\end{array}$ & $\begin{array}{c}11 \\
\text { Arm 1: } 7 \\
\text { Arm 2: } 4\end{array}$ & $\begin{array}{c}10 / 11 \\
\text { Arm 1: } 7 / 7 \\
\text { Arm 2: } 3 / 4\end{array}$ & NA & {$[83]$} \\
\hline Prostate & $\begin{array}{l}\text { hTERT, LAMP } \\
\text { hTERT }\end{array}$ & $\begin{array}{l}\text { Arm 1: } 10^{7} \text { DCs electroporated with } 1 \mu \mathrm{g} \\
\text { hTERT RNA/106 DCs intradermally, } 3 \text { ( } 6 \\
\text { patients) or } 6 \text { ( } 5 \text { patients) times weekly. } \\
\text { Arm 2: } 10^{7} \text { DCs electroporated with } 1 \mu \mathrm{g} \\
\text { LAMP hTERT RNA/106 DCs } \\
\text { intradermally, } 3 \text { ( } 6 \text { patients) or } 6 \text { ( } 3 \\
\text { patients) times weekly. }\end{array}$ & $\begin{array}{c}20 \\
\text { Arm 1: } 11 \\
\text { Arm 2:9 }\end{array}$ & $17 / 18$ & NA & {$[97]$} \\
\hline Prostate & $\begin{array}{l}\text { Total tumor from } \\
\text { prostate cancer cell } \\
\text { lines DU145, } \\
\text { LNCaP, PC-3 }\end{array}$ & $\begin{array}{l}2 \times 10^{7} \text { electroporated DCs intranodally } \\
\text { or intradermally, at least } 4 \text { times weekly. }\end{array}$ & 19 & $12 / 19$ & $11 / 19$ SD & {$[98]$} \\
\hline Melanoma & $\begin{array}{l}\text { Total autologous } \\
\text { tumor }\end{array}$ & $\begin{array}{l}\text { Arm 1: } 2 \times 10^{7} \text { electroporated DCs } \\
\text { intradermally } 4 \text { times weekly. } \\
\text { Arm 2: } 2 \times 10^{7} \text { electroporated DCs } \\
\text { intranodally } 4 \text { times weekly. }\end{array}$ & $\begin{array}{c}22 \\
\text { Arm 1: } 10 \\
\text { Arm 2: } 12\end{array}$ & $9 / 19$ & $2 / 20$ & {$[68]$} \\
\hline Melanoma & $\begin{array}{l}\text { Mage-A3, Mage-C2, } \\
\text { tyrosinase, gp100 }\end{array}$ & $\begin{array}{l}1.25 \times 10^{7} \text { electroporated TriMix DCs } \\
\text { intradermally, } 4 \text { times biweekly. }\end{array}$ & 3 & $2 / 2$ & NA & {$[71]$} \\
\hline
\end{tabular}

NA: Not applicable; SD: Stable disease. 
than 2.5 years. In a parallel study, DCs loaded with CEA mRNA were administered to patients with CEA-expressing tumors (phase I study) or with resected hepatic metastases of colon cancer (phase II study) in escalating doses. While 24 patients were enrolled in the phase I trial, only one showed a complete response, 2 patients exhibited minor responses, and 3 patients showed a stable disease. The clinical response in the phase II study was similarly poor. Nine of 13 patients showed recurrence of disease.

These examples can stand for several clinical phase I/II studies that have been performed and that show an analog outcome. The induction of specific CTLs after vaccination works well and strong immune responses can be observed in vitro, but only little effects are seen when looking at the clinical responses. The majority of the treated patients showed no benefit from the vaccinations; that is, no tumor regression or protection from recurring disease was noticeable. The difference between in vitro analyses and in vivo outcome could be due to the large tumor burden of the patients, the occurrence of regulatory $\mathrm{T}$ cells or myeloid suppressor cells, and induction of tolerance or consequences of medical pretreatment.

Still, scientists have thought of multiple ways to make vaccinations with RNA-transfected DCs more efficient. There are many variables when it comes to the generation of DC vaccines and many issues must be considered. One item is the question of the vaccine dose. This entails in detail the number of administered DCs and if an escalating dose should be used or not, the number of injections, and the injection interval. Another point is the route of administration. Different injection sites are possible for the administration of DC-based vaccines. The cells can be injected intradermally, subcutaneously, intravenously, intranodally, and directly into the tumor. As DCs migrate to lymphatic tissues after their administration, it is subject of investigation which route leads to the most effective immune responses. Intranodal or intradermal close to lymph nodes seemed to be promising, more than i.v. in one trial using peptide-pulsed DCs $[66,67]$. When comparing intradermal versus intranodal injections of RNA-transfected DCs, the intranodal injection showed no signs of superiority $[68,69]$. The different results might be due to the complexity of accurate DC vaccination. Intranodal injections lead to the accumulation of DCs in the lymph nodes. However, the accurate administration is more difficult than i.d. or i.v. injections and vaccines can be accidently delivered into perinodal fat [70]. As the route of administration affects the migration of DCs significantly, the optimal way has to be found for the treatment of different malignancies.

Another important issue is the antigen that has to be transfected into DCs. It is possible to pulse the cells with one or several TAAs or whole cell tumor RNA. Theoretically the application of the latter allows the generation of immune responses against a broad variety of antigens. It is still a matter of investigation if this approach is more effective than the use of several specific TAAs. If enough tumor material is available, whole RNA can be extracted from tumor tissues and used for vaccine preparation. If this is not the case, cDNA libraries can be created followed by cloning, amplification in
E. coli, and finally in vitro transcription of RNA [51]. What actually is an advantage when it comes to the number of patients that can be treated following this approach also has a negative impact on the composition of the RNA mixtures, as in vitro transcription leads to the occurrence of shorter fragments [51].

The actual delivery of RNA into dendritic cells can be achieved in different ways. The transfection can be performed using liposomes and cationic lipids. These bind automatically to RNA due to their charge and form complexes that interact with the target cells. The cationic lipids DOTAP [54] or DMRIE [24] have been used for successful DC transfection. One disadvantage of lipid-mediated transfection is the toxicity of the mixture. Therefore, the ratio between RNA and lipids and the used concentration must be optimized. Another successful approach is the electroporation [71] of dendritic cells in the presence of RNA. The application of an electrical pulse causes the cells to take up enough RNA for antigen presentation. Finally, RNA can be introduced into DCs by passive transfection [72]. Immature DCs absorb particles and media as part of their function without external stimuli. This fact suggests that the cells will take up RNA present in the surroundings of the DCs. The passive RNA pulsing without the use of additives was shown to work successfully as well.

As in vitro experiments showed, the add-on of further stimuli can lead to enhanced immune responses as well. Rains et al. conducted a study on patients suffering from colorectal cancer [73]. They pulsed DCs with tumor RNA and keyhole limpet hemocyanin (KLH) for vaccine preparation. $\mathrm{KLH}$ is an immunogenic protein supposed to enhance the efficiency of the DC vaccination. In the study, eleven of 13 patients developed responses against KLH and seven patients showed a decrease in CEA levels.

A complex in vivo study was performed by Bonehill et al. in which the group generated so-called TriMix DCs [71]. Dendritic cells were electroporated with mRNA encoding CD40L, CD70, and a constitutively active TLR4 as enhancing elements. The cells were additionally electroporated with either Mage-A3, Mage-C2, tyrosinase, or gp100 mRNA. Two melanoma patients received four biweekly intradermal injections at four different sites of $1.25 \times 10^{7}$ TriMix DCs per antigen. While antigen-specific CD8 $\mathrm{T}$ cell responses were detected in both patients after finished treatment, no data about clinical responses were published on this trial.

The discussed approaches have analyzed several possibilities in vaccine preparation and administration. Even more and different settings have to be investigated in the future to find the optimized conditions for this type of treatment.

\section{RNA Vaccines}

Besides using in vitro preparations of dendritic cells for antigen presentation, another approach directly uses RNA vaccines. It has been shown that RNA can be transfected into DCs without the help of additives like liposomes or electroporation. Therefore, an obvious approach is the vaccination with naked RNA. 
To deliver mRNA into patients in an effective manner, several issues have already been considered and tried out. RNA molecules themselves are thought to be relatively instable and easily degradable. For this reason there used to be much doubt, if the injection of the naked RNA molecules makes sense. However, Wolff et al. injected naked RNA into the skeletal muscle of mice and showed that the encoded protein was expressed in situ [74]. Furthermore, it could be shown that even the application of unprotected RNA could induce specific CTL responses in patients. Still, some thought has been given to stabilize RNA molecules and make delivery more efficient.

One possibility for RNA administration is to code the nucleic acid on gold particles and subsequent "gene-gun delivery" [75]. The particles are used as shuttles to carry the RNA molecules through skin. After incorporation by DCs, the encoded proteins are expressed and presented to T cells.

Another approach, which has been analyzed, is the packaging of RNA into liposomes. Liposomes contain cationic lipids which interact electrostatically with negatively charged nucleic acid molecules and form stable complexes [76]. Liposomes not only stabilize RNA, but already activate immune cells by themselves, and thus are supporting as adjuvants $[77,78]$.

Another way to stabilize RNA is its condensation to protamine [52], an arginine-rich protein essential for DNA condensation in spermatogenesis. Protamine forms spontaneous complexes with RNA in vitro, which are immunostimulating for several hours. Besides protection of RNA, protamine functions as a danger signal and activates in a MyD88dependent way human DCs as well as monocytes, B cells, NK cells, and granulocytes.

Other ways to modify RNA to make it more resistant against degradation and more efficient for translation are the elongation of the poly-A tail at the $3^{\prime}$-end of the molecule and the manipulation of the Cap structure at the $5^{\prime}$-end. If the original 7-methylguanosine triphosphate is replaced by an Antireverse Cap Analog (ARCA), the efficiency of transcription is strongly enhanced.

To provide the immune system with even more potent signals, RNA has been modified to generate sequences with a phosphorothioate backbone [79]. Phosphothioate RNA serves as a danger signal and activates mouse DCs through MyD88 [79].

As discussed in connection with RNA-transfected DCs, the optimal injection site for immunostimulatory RNA has been a matter of research. RNA alone can be injected using the following routes: subcutaneous, intradermal, intramuscular, and intranodal. Injections close or into the lymph nodes seem to be preferable, as they induce the generation of strong immune responses.

By now, several in vivo studies have been carried out to analyze the use of RNA in tumor vaccines. Carralot et al. injected $\beta$-globin UTR-stabilized RNA encoding $\beta$ galactosidase intradermally into $\mathrm{BALB} / \mathrm{c}$ mice [80]. The model antigen was translated in vivo, which was shown by specific staining. Interestingly, IgG1 antibodies against $\beta$-galactosidase were found after the vaccination, which are characteristic for a TH2 immune response. This result seemed to be contrary to other studies using DNA vaccines, where the generation of IgG2 antibodies was induced. The latter is typical for a TH1 response, which is preferred in antitumor immunotherapy. The study showed the importance of the type of antigen used for the vaccine in means of DNA or RNA, as it is obviously more important than the delivery route.

Until now, only few phase I/II trials have been carried out using RNA as a vaccine (see Table 2). Schmidt et al. vaccinated 30 RCC patients with naked tumor RNA coding for the TAAs MUC1, CEA, Her-2/neu, telomerase, surviving, and MAGE- 1 . The patients received intradermal injections on days $1,14,28$, and 42 (group A), while group $\mathrm{B}$ received vaccinations on days $0-3,7-10,28$, and 42 following monthly injections. The generation of antigen-specific immune responses was analyzed in vitro by ELISPOT assays. Both CD4+ and CD8+ T cell responses were induced for diverse antigens. Seven patients additionally showed a clinical response. No severe adverse effects occurred demonstrating the safety of the approach [81].

Weide et al. carried out two distinct trials on metastatic melanoma $[5,82]$. In the first phase I/II study patients with stages III and IV received intradermal injections of in vitro transcribed naked whole tumor RNA. The patients were vaccinated with four times every two weeks followed by monthly injections for six months. 24 hours after each vaccination, the patients were injected subcutaneously with GM-CSF as an adjuvant. After treatment, melanoma cell line-specific antibodies were detected in four of 15 patients and specific $\mathrm{T}$ cell responses were probably induced in five patients. Looking at the clinical response, two patients showed a mixed response and five patients a favourable course of disease, but no clinical regression was seen. The vaccine itself proved to be safe, as only mild and reversible side effects occurred.

In the second phase I/II study, not whole tumor RNA was used for vaccination, but six defined RNAs encoding the TAAs Melan-A, tyrosinase, gp100, Mage-A1, Mage-A3, and survivin. The metastatic melanoma patients received escalating doses of RNA, a higher number of injections in comparison to the first study, and instead of using naked RNA the nucleic acids were stabilized with protamine. Additionally, KLH was used as a helper antigen and added to the vaccine of half of the patients. Again, GM-CSF was injected 24 hours after vaccination. The intense vaccination schedule contained 12 vaccinations administered in 19 weeks. The analysis of induced $\mathrm{T}$ cell responses showed no consistency between different patients. Out of four patients, one showed an increase in CD8 and CD4 T cells, a second patient showed first an increase for both $\mathrm{T}$ cell populations, but then a decline and no difference was seen in two other patients. The few number of patients and the individual differences make the outcome uncertain. In addition, the numbers of immunosuppressive cells were monitored. While the KLH+ arm exhibited a decrease of regulatory $\mathrm{T}$ cells (Tregs), the $\mathrm{KLH}$-arm showed a decrease in myeloid suppressor cells. A clinical response was seen in one of seven stage IV patients. Again, the study results showed only few achievements by the administered immunotherapy. The group pointed in their 
TABLE 2: Recent clinical trials using RNA.

\begin{tabular}{|c|c|c|c|c|c|c|}
\hline Cancer type & RNA & Vaccination schedule & $\begin{array}{c}\text { Number of } \\
\text { study subjects }\end{array}$ & $\begin{array}{l}\text { Immunological } \\
\text { response }\end{array}$ & Clinical response & Reference \\
\hline Melanoma & Total tumor & $\begin{array}{l}200 \mu \mathrm{g} \text { naked RNA intradermally, } \\
\text { biweekly for } 8 \text { weeks, followed by } \\
\text { monthly injections for } 6 \text { months. } \\
150 \mu \mathrm{g} \text { GM-CSF subcutaneously } 24 \mathrm{~h} \\
\text { after RNA injection. }\end{array}$ & 15 & NA & $\begin{array}{l}\text { 2/13 MR } \\
\text { 3/13 NED }\end{array}$ & {$[5]$} \\
\hline Melanoma & $\begin{array}{l}\text { Melan-A, } \\
\text { tyrosinase, } \\
\text { gp100, } \\
\text { Mage-A1, } \\
\text { Mage-A3, } \\
\text { survivin }\end{array}$ & $\begin{array}{l}\text { Arm } 1: 3.2-80 \mu \text { g RA per antigen }+ \\
128 \mu \text { g protamine intradermally on } \\
\text { days } 1,3,5 \text {, weeks } 2,3,4,5,6,7,11,15 \text {, } \\
\text { 19. } 200 \mu \mathrm{g} \text { GM-CSF subcutaneously } 24 \\
\text { h after RNA injection. } \\
\text { Arm } 2: 3.2-80 \mu \mathrm{g} \text { RNA per antigen }+ \\
128 \mu \text { g protamine }+4 \text { mg KLH } \\
\text { intradermally on days } 1,3,5 \text {, weeks } 2 \text {, } \\
3,4,5,6,7,11,15,19.200 \mu \mathrm{g} \text { GM-CSF } \\
\text { subcutaneously } 24 \mathrm{~h} \text { after RNA } \\
\text { injection. }\end{array}$ & $\begin{array}{c}21 \\
\text { Arm 1: } 11 \\
\text { Arm 2: } 10\end{array}$ & $\begin{array}{l}\text { Vaccine directed T } \\
\text { cells: } 2 / 4\end{array}$ & $\begin{array}{c}\text { Arm 1: } 1 / 11 \text { CR } \\
\text { 4/11 NED } \\
\text { Arm 2: } 1 / 10 \text { NED }\end{array}$ & {$[99]$} \\
\hline RCC & $\begin{array}{l}\text { MUC1, CEA, } \\
\text { Her-2/neu, } \\
\text { telomerase, } \\
\text { surviving, } \\
\text { MAGE-1 }\end{array}$ & $\begin{array}{l}\text { Arm 1: } 20 \mu \mathrm{g} \text { naked RNA per antigen } \\
\text { intradermally on days } 0,14,28,42, \\
\text { followed by monthly injections. } \\
100 \mu \mathrm{g} / \mathrm{m}^{2} \mathrm{GM}-\mathrm{CSF} \text { subcutaneously } 24 \\
\mathrm{~h} \text { after RNA injection. } \\
\text { Arm } 2: 50 \mu \mathrm{g} \text { naked RNA per antigen } \\
\text { intradermally on days } 0-3,7-10,28, \\
42, \text { followed by monthly injections. } \\
250 \mu \mathrm{g} / \mathrm{m}^{2} \text { GM-CSF subcutaneously } \\
24 \mathrm{~h} \text { after RNA injection. }\end{array}$ & $\begin{array}{c}\text { 30, } \\
\text { Arm 1: } 14 \\
\text { Arm 2: } 16\end{array}$ & $\begin{array}{c}\text { CD4+ ELISpot: } 3 / 7 \\
\text { CD8+ ELISpot: } 8 / 9 \\
\text { CD8+ Cr-Release } \\
\text { Assay: } 7 / 11\end{array}$ & $\begin{array}{l}\text { Arm 1: } \\
\text { 1/14 PR } \\
\text { 6/14 SD } \\
\text { Arm 2: } \\
\text { 9/16 SD }\end{array}$ & {$[81]$} \\
\hline
\end{tabular}

CR: Complete response; MR: Mixed response; NA: Not applicable; NED: No evidence of disease; PR: Partial response; SD: Stable disease.

report to the possible role of immunosuppressive cells for the treatment. This issue is eventually one reason why there is a huge discrepancy in clinical trials when comparing the generation of specific antitumor immune responses in vitro and the clinical response of patients.

\section{Optimization of Immunotherapy}

CD4+CD25+ regulatory $\mathrm{T}$ cells are important for selftolerance and have suppressor functions in the immune system. They control immune responses and reduce the risk of $\mathrm{T}$ cell responses being harmful to the body. Elevated numbers of Tregs are linked to a reduced survival in tumor patients. Thus, the depletion of Tregs could prolong the life of patients and strengthen the induced immune responses.

Dannull et al. vaccinated RCC patients with RNAtransfected DCs and additionally reduced the number of regulatory $\mathrm{T}$ cells [83]. For the depletion of Tregs they used the recombinant IL-2 diphtheria toxin conjugate $\mathrm{DAB}_{389} \mathrm{IL}-$ 2 (ONTAK), which selectively eliminates CD25-positive regulatory T cells. A significant increase of tumor-specific CD8 and CD4 $\mathrm{T}$ cell responses was observed for the combinational therapy opposed to injections with DC vaccines alone.

Another approach to eliminate inhibitory immune mechanisms is the targeting of CTLA-4. Cytotoxic T lymphocyte antigen (CTLA)-4 is homologous to the costimulatory $\mathrm{B} 7$ molecules and a negative regulator for $\mathrm{T}$ cell proliferation. Like B7, CTLA-4 binds to CD28. However, the affinity of
CTLA-4 to CD28 is higher in comparison to B7 and the interaction leads to the inhibition of $\mathrm{T}$ cell proliferation. After $\mathrm{T}$ cell activation, CTLA-4 expression is increased, making the interaction with CD28 more and more likely and giving a negative feedback mechanism. The importance of CTLA-4 is pointed out by certain CTLA-4 polymorphisms which lead to autoimmune diseases [84]. Another evidence for the importance in controlling $\mathrm{T}$ cell responses is found in mice with lympho-proliferatory diseases not expressing CTLA-4 [85, 86].

The inhibition of CTLA-4 could lead to the generation of enhanced $\mathrm{T}$ cell responses. Tremelimumab and Ipilimumab are both humanized anti-CTLA-4 inhibitory antibodies. Their application in melanoma trials led to better clinical responses in treated patients [87]. Along with these promising results went severe side effects like diarrhea, panhypopituitarism, and autoimmune thyroiditis. These immune-related adverse events (IRAEs) probably go along with positive clinical responses. Further investigation should stress on the safety issues of CTLA-4 inhibition, as long-time treatment could lead to autoimmune phenomena. In ongoing studies the utilization of several immunemodulatory mechanisms together with CTLA-4 inhibition is investigated [88].

Besides the inhibition of undesirable immune effects, it is possible to further stimulate mechanisms that activate the immune system. Compounds with enhancing qualities are, for instance, nonmethylated cytosine-guanine dinucleotides 
(CpGs) $[89,90]$. These synthetic oligodeoxynucleotides are homologues to bacterial or viral DNA and stimulate TLR9. TLR9 is a pattern-recognition receptor belonging to the TLR family. It is located in the endosomal compartments of dendritic cells and macrophages and activates APCs at the occurrence of PAMPS. The synthetic oligodeoxynucleotide PF-3512676, for instance, enhances the induced immune response and prevents induction of immune tolerance [91].

Another possibility to enhance antitumor effects is the combination of RNA-vaccination with the administration of tyrosine kinase inhibitors (TKIs). The TKIs sorafenib and sunitinib inhibit intracellular signaling pathways leading to proliferation and angiogenesis. Sorafenib is applied in the therapy of renal cell carcinoma (RCC) and hepatocellular carcinoma (HCC). Sunitinib is administered in RCC and gastrointestinal tumor (GIST) treatment. Recent mouse experiments showed that pretreatment with sorafenib reduced the induction of antigen-specific $\mathrm{T}$ cells, while sunitinib had no such effect [92]. In human monocytederived DCs, sunitinib had no influence on DC phenotype and $\mathrm{T}$ cell proliferation, but sorafenib inhibited maturation processes in DCs and the stimulation of $\mathrm{T}$ cells. These findings indicate that sunitinib might be a good choice for combinational therapy with RNA vaccinations.

\section{Summary}

In the last 20 years many research groups have focused on the development of immunotherapies to fight malignant diseases. The main idea behind this approach is the utilization of apparent differences between the tumor and the normal healthy tissue it originated from. An important discovery supporting ongoing experiments was the finding of tumor-associated antigens, which demonstrate the difference of altered tissues on the molecular level. TAAs have been the starting point for several in vitro experiments and in vivo studies to generate specific immune responses against tumor cells.

One feasible and apparently safe approach for vaccination is the usage of mRNA encoding TAAs or the use of whole tumor RNA altogether. RNA can be used to transfect dendritic cells, which present TAAs, in their function as antigen-presenting cells, to $\mathrm{T}$ cells and generate a specific immune response. In more recent studies, the use of naked RNA plus possible enhancers has been analyzed in vaccination trials as well. For both methods exist a broad variety of variables that can be modified at vaccine administration. Due to this diversity, ongoing trials basically never follow the same approach twice, but instead single items are systematically changed for each new study. Many more trials might be needed before the best vaccination schemes will be found. However, the use of RNA vaccination might be the key for the cure of diverse types of malignant diseases.

Until now, in vivo trials have in common that the generation of specific $\mathrm{T}$ cells is induced after the vaccination of patients, but clinical outcomes are observed rarely. Often, the progression or recurrence of disease is observed instead of tumor clearance. Thus, latest studies deal with the enhancement of the effectiveness of vaccines. One possibility is the combination of RNA vaccination and the further stimulation of the immune system by cytokines and TLR ligands together with the inhibition of cell populations that suppress immune responses. When the most effective vaccination mechanisms will be found, patients will receive a specific treatment against their individual disease. The stimulation of the patient's immune system will lead to the generation and maintenance of an effective immune response. Hopefully, the vaccination with RNA will enable the control of malignant disease.

\section{References}

[1] Y. H. Pilch, J. B. de Kernion, D. G. Skinner, et al., "Immunotherapy of cancer with "immune" RNA. A preliminary report," The American Journal of Surgery, vol. 132, no. 5, pp. 631-637, 1976.

[2] Y. H. Pilch, K. P. Ramming, and J. B. DeKernion, "Preliminary studies of specific immunotherapy of cancer with immune RNA," Cancer, vol. 40, no. 5, pp. 2747-2757, 1977.

[3] G. Steele Jr., B. S. Wang, J. Richie, et al., "In vivo effect and parallel in vitro lymphocyte-mediated tumor cytolysis after phase I xenogeneic immune RNA treatment of patients with widespread melanoma or metastatic renal cell carcinoma," Cancer Research, vol. 40, no. 7, pp. 2377-2382, 1980.

[4] I. Hoerr, R. Obst, H.-G. Rammensee, and G. Jung, "In vivo application of RNA leads to induction of specific cytotoxic T lymphocytes and antibodies," European Journal of Immunology, vol. 30, no. 1, pp. 1-7, 2000.

[5] B. Weide, J.-P. Carralot, A. Reese, et al., "Results of the first phase I/II clinical vaccination trial with direct injection of mRNA," Journal of Immunotherapy, vol. 31, no. 2, pp. 180-188, 2008.

[6] P. van der Bruggen, C. Traversari, P. Chomez, et al., "A gene encoding an antigen recognized by cytolytic T lymphocytes on a human melanoma," Science, vol. 254, no. 5038, pp. 16431647, 1991.

[7] P. G. Coulie, V. Brichard, A. Van Pel, et al., "A new gene coding for a differentiation antigen recognized by autologous cytolytic T lymphocytes on HLA-A2 melanomas," The Journal of Experimental Medicine, vol. 180, no. 1, pp. 35-42, 1994.

[8] O. L. Caballero and Y.-T. Chen, "Cancer/testis (CT) antigens: potential targets for immunotherapy," Cancer Science, vol. 100, no. 11, pp. 2014-2021, 2009.

[9] Y.-T. Chen, M. J. Scanlan, U. Sahin, et al., "A testicular antigen aberrantly expressed in human cancers detected by autologous antibody screening," Proceedings of the National Academy of Sciences of the United States of America, vol. 94, no. 5, pp. 19141918, 1997.

[10] T. Wolfel, M. Hauer, J. Schneider, et al., "A p16(INK4a)insensitive CDK4 mutant targeted by cytolytic T lymphocytes in a human melanoma," Science, vol. 269, no. 5228, pp. 12811284, 1995.

[11] B. Fossum, T. Gedde-Dahl III, T. Hansen, J. A. Eriksen, E. Thorsby, and G. Gaudernack, "Overlapping epitopes encompassing a point mutation (12Gly $\rightarrow$ Arg) in p21 ras can be recognized by HLA-DR, -DP and -DQ restricted T cells," European Journal of Immunology, vol. 23, no. 10, pp. 26872691, 1993. 
[12] S. Mandruzzato, F. Brasseur, G. Andry, T. Boon, and P. Van der Bruggen, "A CASP-8 mutation recognized by cytolytic $\mathrm{T}$ lymphocytes on a human head and neck carcinoma," The Journal of Experimental Medicine, vol. 186, no. 5, pp. 785-793, 1997.

[13] S. Markowitz, J. Wang, L. Myeroff, et al., "Inactivation of the type II TGF- $\beta$ receptor in colon cancer cells with microsatellite instability," Science, vol. 268, no. 5215, pp. 1336-1338, 1995.

[14] R. Parsons, L. L. Myeroff, B. Liu, et al., "Microsatellite instability and mutations of the transforming growth factor $\beta$ type II receptor gene in colorectal cancer," Cancer Research, vol. 55, no. 23, pp. 5548-5550, 1995.

[15] I. Saeterdal, M. K. Gjertsen, P. Straten, et al., "A TGF betaRII frameshift-mutation-derived CTL epitope recognised by HLA-A2-restricted CD8 ${ }^{+} \mathrm{T}$ cells," Cancer Immunology, Immunotherapy, vol. 50, pp. 469-476, 2001.

[16] A. B. H. Bakker, M. W. J. Schreurs, A. J. de Boer, et al., "Melanocyte lineage-specific antigen gp100 is recognized by melanoma-derived tumor-infiltrating lymphocytes," The Journal of Experimental Medicine, vol. 179, no. 3, pp. 10051009, 1994.

[17] V. Brichard, A. Van Pel, T. Wolfel, et al., "The tyrosinase gene codes for an antigen recognized by autologous cytolytic T lymphocytes on HLA-A2 melanomas," The Journal of Experimental Medicine, vol. 178, no. 2, pp. 489-495, 1993.

[18] T. Wolfel, A. Van Pel, V. Brichard, et al., "Two tyrosinase nonapeptides recognized on HLA-A2 melanomas by autologous cytolytic T lymphocytes," European Journal of Immunology, vol. 24, no. 3, pp. 759-764, 1994.

[19] C. Adida, C. Haioun, P. Gaulard, et al., "Prognostic significance of survivin expression in diffuse large B-cell lymphomas," Blood, vol. 96, no. 5, pp. 1921-1925, 2000.

[20] D. Grossman, J. M. McNiff, F. Li, and D. C. Altieri, "Expression and targeting of the apoptosis inhibitor, survivin, in human melanoma," Journal of Investigative Dermatology, vol. 113, no. 6, pp. 1076-1081, 1999.

[21] S. M. Schmidt, K. Schag, M. R. Muller, et al., "Survivin is a shared tumor-associated antigen expressed in a broad variety of malignancies and recognized by specific cytotoxic T cells," Blood, vol. 102, no. 2, pp. 571-576, 2003.

[22] P. Brossart, A. Schneider, P. Dill, et al., "The epithelial tumor antigen MUC1 is expressed in hematological malignancies and is recognized by MUC1-specific cytotoxic T-lymphocytes," Cancer Research, vol. 61, no. 18, pp. 6846-6850, 2001.

[23] A. Girling, J. Bartkova, J. Burchell, S. Gendler, C. Gillett, and J. Taylor-Paradimitriou, "A core protein epitope of the polymorphic epithelial mucin detected by the monoclonal antibody SM-3 is selectively exposed in a range of primary carcinomas," International Journal of Cancer, vol. 43, no. 6, pp. 1072-1076, 1989.

[24] S. K. Nair, D. Boczkowski, M. Morse, R. I. Cumming, H. K. Lyerly, and E. Gilboa, "Induction of primary carcinoembryonic antigen (CEA)-specific cytotoxic T lymphocytes in vitro using human dendritic cells transfected with RNA," Nature Biotechnology, vol. 16, no. 4, pp. 364-369, 1998.

[25] F. K. Rae, S.-A. Stephenson, D. L. Nicol, and J. A. Clements, "Novel association of a diverse range of genes with renal cell carcinoma as identified by differential display," International Journal of Cancer, vol. 88, no. 5, pp. 726-732, 2000.

[26] S. M. Schmidt, K. Schag, M. R. Muller, et al., "Induction of adipophilin-specific cytotoxic $\mathrm{T}$ lymphocytes using a novel HLA-A2-binding peptide that mediates tumor cell lysis," Cancer Research, vol. 64, no. 3, pp. 1164-1170, 2004.
[27] Y. Yokoyama, F. Grunebach, S. M. Schmidt, et al., "Matrilysin (MMP-7) is a novel broadly expressed tumor antigen recognized by antigen-specific T cells," Clinical Cancer Research, vol. 14, no. 17, pp. 5503-5511, 2008.

[28] F. Grunebach, S. Erndt, M. Hantschel, A. Heine, and P. Brossart, "Generation of antigen-specific CTL responses using RGS1 mRNA transfected dendritic cells," Cancer Immunology, Immunotherapy, vol. 57, no. 10, pp. 1483-1491, 2008.

[29] C. N. Boss, F. Grunebach, K. Brauer, et al., "Identification and characterization of T-cell epitopes deduced from RGS5, a novel broadly expressed tumor antigen," Clinical Cancer Research, vol. 13, no. 11, pp. 3347-3355, 2007.

[30] Y. Oka, O. A. Elisseeva, A. Tsuboi, et al., "Human cytotoxic T-lymphocyte responses specific for peptides of the wild-type Wilms' tumor gene (WT1) product," Immunogenetics, vol. 51, no. 2, pp. 99-107, 2000.

[31] J. Molldrem, S. Dermime, K. Parker, et al., "Targeted T-cell therapy for human leukemia: cytotoxic T lymphocytes specific for a peptide derived from proteinase 3 preferentially lyse human myeloid leukemia cells," Blood, vol. 88, no. 7, pp. 24502457, 1996.

[32] J. J. Molldrem, E. Clave, Y. Z. Jiang, et al., "Cytotoxic $\mathrm{T}$ lymphocytes specific for a nonpolymorphic proteinase 3 peptide preferentially inhibit chronic myeloid leukemia colony-forming units," Blood, vol. 90, no. 7, pp. 2529-2534, 1997.

[33] J. Greiner, M. Ringhoffer, M. Taniguchi, et al., "Receptor for hyaluronan acid-mediated motility (RHAMM) is a new immunogenic leukemia-associated antigen in acute and chronic myeloid leukemia," Experimental Hematology, vol. 30, no. 9, pp. 1029-1035, 2002.

[34] S. M. Schmidt, T. Konig, A. Bringmann, et al., "Characterization of BAX inhibitor-1 as a novel leukemia-associated antigen," Leukemia, vol. 23, no. 10, pp. 1818-1824, 2009.

[35] K. Inaba, S. Turley, T. Iyoda, et al., "The formation of immunogenic major histocompatibility complex class IIpeptide ligands in lysosomal compartments of dendritic cells is regulated by inflammatory stimuli," The Journal of Experimental Medicine, vol. 191, no. 6, pp. 927-936, 2000.

[36] K. Inaba, M. Witmer-Pack, M. Inaba, et al., "The tissue distribution of the B7-2 costimulator in mice: abundant expression on dendritic cells in situ and during maturation in vitro," The Journal of Experimental Medicine, vol. 180, no. 5, pp. 1849-1860, 1994.

[37] C. Caux, C. Massacrier, B. Vanbervliet, et al., "Activation of human dendritic cells through CD40 cross-linking," The Journal of Experimental Medicine, vol. 180, no. 4, pp. 12631272, 1994.

[38] D. N. Hart and T. C. Prickett, "Intercellular adhesion molecule-2 (ICAM-2) expression on human dendritic cells," Cellular Immunology, vol. 148, pp. 447-454, 1993.

[39] K. Inaba and R. M. Steinman, "Monoclonal antibodies to LFA-1 and to CD4 inhibit the mixed leukocyte reaction after the antigen-dependent clustering of dendritic cells and $\mathrm{T}$ lymphocytes," The Journal of Experimental Medicine, vol. 165, no. 5, pp. 1403-1417, 1987.

[40] T. C. R. Prickett, J. L. McKenzie, and D. N. J. Hart, "Adhesion molecules on human tonsil dendritic cells," Transplantation, vol. 53, no. 2, pp. 483-490, 1992.

[41] M. J. Bevan, "Cross-priming for a secondary cytotoxic response to minor $\mathrm{H}$ antigens with $\mathrm{H}-2$ congenic cells which do not cross-react in the cytotoxic assay," The Journal of Experimental Medicine, vol. 143, pp. 1283-1288, 1976. 
[42] M. J. Bevan, "Priming for a cytotoxic response to minor histocompatibility antigens: antigen specificity and failure to demonstrate a carrier effect," Journal of Immunology, vol. 118, no. 4, pp. 1370-1374, 1977.

[43] P. Brossart and M. J. Bevan, "Presentation of exogenous protein antigens on major histocompatability complex class I molecules by dendritic cells: pathway of presentation and regulation by cytokines," Blood, vol. 90, no. 4, pp. 1594-1599, 1997.

[44] C. Caux, C. Dezutter-Dambuyant, D. Schmit, and J. Banchereau, "GM-CSF and TNF- $\alpha$ cooperate in the generation of dendritic Langerhans cells," Nature, vol. 360, no. 6401, pp. 258-261, 1992.

[45] C. Caux, B. Vanbervliet, C. Massacrier, et al., "CD34 hematopoietic progenitors from human cord blood differentiate along two independent dendritic cell pathways in response to GM-CSF+TNF $\alpha$," The Journal of Experimental Medicine, vol. 184, no. 2, pp. 695-706, 1996.

[46] K. Inaba, M. Inaba, N. Romani, et al., "Generation of large numbers of dendritic cells from mouse bone marrow cultures supplemented with granulocyte/macrophage colonystimulating factor," The Journal of Experimental Medicine, vol. 176, no. 6, pp. 1693-1702, 1992.

[47] J. H. Peters, H. Xu, J. Ruppert, D. Ostermeier, D. Friedrichs, and R. K. H. Gieseler, "Signals required for differentiating dendritic cells from human monocytes in vitro," Advances in Experimental Medicine and Biology, vol. 329, pp. 275-280, 1993.

[48] N. Romani, S. Gruner, D. Brang, et al., "Proliferating dendritic cell progenitors in human blood," The Journal of Experimental Medicine, vol. 180, no. 1, pp. 83-93, 1994.

[49] F. Sallusto and A. Lanzavecchia, "Efficient presentation of soluble antigen by cultured human dendritic cells is maintained by granulocyte/macrophage colony-stimulating factor plus interleukin 4 and downregulated by tumor necrosis factor $\alpha$," The Journal of Experimental Medicine, vol. 179, no. 4, pp. 1109-1118, 1994.

[50] A. W. Lee, T. Truong, K. Bickham, et al., "A clinical grade cocktail of cytokines and PGE2 results in uniform maturation of human monocyte-derived dendritic cells: implications for immunotherapy," Vaccine, vol. 20, supplement 4, pp. A8-A22, 2002.

[51] J.-P. Carralot, B. Weide, O. Schoor, et al., "Production and characterization of amplified tumor-derived cRNA libraries to be used as vaccines against metastatic melanomas," Genetic Vaccines and Therapy, vol. 3, article 6, 2005.

[52] B. Scheel, R. Teufel, J. Probst, et al., "Toll-like receptordependent activation of several human blood cell types by protamine-condensed mRNA," European Journal of Immunology, vol. 35, no. 5, pp. 1557-1566, 2005.

[53] B. Scheel, S. Aulwurm, J. Probst, et al., "Therapeutic antitumor immunity triggered by injections of immunostimulating single-stranded RNA," European Journal of Immunology, vol. 36, no. 10, pp. 2807-2816, 2006.

[54] D. Boczkowski, S. K. Nair, D. Snyder, and E. Gilboa, "Dendritic cells pulsed with RNA are potent antigen-presenting cells in vitro and in vivo," The Journal of Experimental Medicine, vol. 184, no. 2, pp. 465-472, 1996.

[55] C. Milazzo, V. L. Reichardt, M. R. Muller, F. Grunebach, and P. Brossart, "Induction of myeloma-specific cytotoxic T cells using dendritic cells transfected with tumor-derived RNA," Blood, vol. 101, no. 3, pp. 977-982, 2003.
[56] A. Heiser, M. A. Maurice, D. R. Yancey, D. M. Coleman, P. Dahm, and J. Vieweg, "Human dendritic cells transfected with renal tumor RNA stimulate polyclonal T-cell responses against antigens expressed by primary and metastatic tumors," Cancer Research, vol. 61, no. 8, pp. 3388-3393, 2001.

[57] F. Grunebach, K. Kayser, M. M. Weck, M. R. Muller, S. Appel, and P. Brossart, "Cotransfection of dendritic cells with RNA coding for HER-2/neu and 4-1BBL increases the induction of tumor antigen specific cytotoxic T lymphocytes," Cancer Gene Therapy, vol. 12, no. 9, pp. 749-756, 2005.

[58] M. W. Onaitis, M. F. Kalady, S. Emani, Z. Abdel-Wahab, D. S. Tyler, and S. K. Pruitt, "CD40 ligand is essential for generation of specific cytotoxic T cell responses in RNA-pulsed dendritic cell immunotherapy," Surgery, vol. 134, no. 2, pp. 300-305, 2003.

[59] M. F. Kalady, M. W. Onaitis, S. Emani, Z. Abdel-Wahab, D. S. Tyler, and S. K. Pruitt, "Sequential delivery of maturation stimuli increases human dendritic cell IL-12 production and enhances tumor antigen-specific immunogenicity," Journal of Surgical Research, vol. 116, no. 1, pp. 24-31, 2004.

[60] Z. Abdel-Wahab, R. Cisco, J. Dannull, et al., "Cotransfection of DC with TLR4 and MART-1 RNA induces MART-1specific responses," Journal of Surgical Research, vol. 124, no. 2, pp. 264-273, 2005.

[61] M. F. Kalady, M. W. Onaitis, K. M. Padilla, S. Emani, D. S. Tyler, and S. K. Pruitt, "Enhanced dendritic cell antigen presentation in RNA-based immunotherapy," Journal of Surgical Research, vol. 105, no. 1, pp. 17-24, 2002.

[62] T. Naka, M. Iwahashi, M. Nakamura, et al., "Tumor vaccine therapy against recrudescent tumor using dendritic cells simultaneously transfected with tumor RNA and granulocyte macrophage colony-stimulating factor RNA," Cancer Science, vol. 99, no. 2, pp. 407-413, 2008.

[63] S.-G. Kim, M.-Y. Park, C.-H. Kim, et al., "Modification of CEA with both CRT and TAT PTD induces potent anti-tumor immune responses in RNA-pulsed DC vaccination," Vaccine, vol. 26, no. 50, pp. 6433-6440, 2008.

[64] A. Heiser, D. Coleman, J. Dannull, et al., "Autologous dendritic cells transfected with prostate-specific antigen RNA stimulate CTL responses against metastatic prostate tumors," Journal of Clinical Investigation, vol. 109, no. 3, pp. 409-417, 2002.

[65] M. A. Morse, S. K. Nair, D. Boczkowski, et al., "The feasibility and safety of immunotherapy with dendritic cells loaded with CEA mRNA following neoadjuvant chemoradiotherapy and resection of pancreatic cancer," International Journal of Gastrointestinal Cancer, vol. 32, no. 1, pp. 1-6, 2002.

[66] I. Bedrosian, R. Mick, S. Xu, et al., "Intranodal administration of peptide-pulsed mature dendritic cell vaccines results in superior CD8 ${ }^{+}$T-cell function in melanoma patients," Journal of Clinical Oncology, vol. 21, no. 20, pp. 3826-3835, 2003.

[67] L. Fong, D. Brockstedt, C. Benike, L. Wu, and E. G. Engleman, "Dendritic cells injected via different routes induce immunity in cancer patients," Journal of Immunology, vol. 166, no. 6, pp. 4254-4259, 2001.

[68] J. A. Kyte, L. Mu, S. Aamdal, et al., "Phase I/II trial of melanoma therapy with dendritic cells transfected with autologous tumor-mRNA," Cancer Gene Therapy, vol. 13, no. 10, pp. 905-918, 2006.

[69] S. Dueland, L. J. Mu, G. Kvalheim, et al., "Dendritic cells transfected with allo-tumor mRNA as cancer vaccine in treatment of hormone resistant prostate cancer patients," Journal of Clinical Oncology, vol. 23, no. 16s, 2005, abstract no. 2541. 
[70] I. J. M. de Vries, W. J. Lesterhuis, J. O. Barentsz, et al., "Magnetic resonance tracking of dendritic cells in melanoma patients for monitoring of cellular therapy," Nature Biotechnology, vol. 23, no. 11, pp. 1407-1413, 2005.

[71] A. Bonehill, A. M. T. Van Nuffel, J. Corthals, et al., "Single-step antigen loading and activation of dendritic cells by mRNA electroporation for the purpose of therapeutic vaccination in melanoma patients," Clinical Cancer Research, vol. 15, no. 10, pp. 3366-3375, 2009.

[72] Z. Su, J. Dannull, A. Heiser, et al., "Immunological and clinical responses in metastatic renal cancer patients vaccinated with tumor RNA-transfected dendritic cells," Cancer Research, vol. 63, no. 9, pp. 2127-2133, 2003.

[73] N. Rains, R. J. Cannan, W. Chen, and R. S. Stubbs, “Development of a dendritic cell (DC)-based vaccine for patients with advanced colorectal cancer," Hepato-Gastroenterology, vol. 48, no. 38, pp. 347-351, 2001.

[74] J. A. Wolff, R. W. Malone, P. Williams, et al., "Direct gene transfer into mouse muscle in vivo," Science, vol. 247, no. 4949, pp. 1465-1468, 1990.

[75] P. Qiu, P. Ziegelhoffer, J. Sun, and N. S. Yang, "Gene gun delivery of mRNA in situ results in efficient transgene expression and genetic immunization," Gene Therapy, vol. 3, no. 3, pp. 262-268, 1996.

[76] R. W. Malone, P. L. Felgner, and I. M. Verma, "Cationic liposome-mediated RNA transfection," Proceedings of the National Academy of Sciences of the United States of America, vol. 86, no. 16, pp. 6077-6081, 1989.

[77] S. Espuelas, A. Roth, C. Thumann, B. Frisch, and F. Schuber, "Effect of synthetic lipopeptides formulated in liposomes on the maturation of human dendritic cells," Molecular Immunology, vol. 42, no. 6, pp. 721-729, 2005.

[78] K. S. Korsholm, E. M. Agger, C. Foged, et al., "The adjuvant mechanism of cationic dimethyldioctadecylammonium liposomes," Immunology, vol. 121, no. 2, pp. 216-226, 2007.

[79] B. Scheell, S. Braedel, J. Probst, et al., "Immunostimulating capacities of stabilized RNA molecules," European Journal of Immunology, vol. 34, no. 2, pp. 537-547, 2004.

[80] J.-P. Carralot, J. Probst, I. Hoerr, et al., "Polarization of immunity induced by direct injection of naked sequencestabilized mRNA vaccines," Cellular and Molecular Life Sciences, vol. 61, no. 18, pp. 2418-2424, 2004.

[81] S. M. Schmidt, M. Haentschel, and M. R. Mueller, "Vaccinations with RNA coding for tumor associated antigens in advanced RCC patients - a phase I/II study," Journal of Clinical Oncology, vol. 16, supplement, 2008, abstract no. 3017 .

[82] B. Weide, C. Garbe, H.-G. Rammensee, and S. Pascolo, "Plasmid DNA- and messenger RNA-based anti-cancer vaccination," Immunology Letters, vol. 115, no. 1, pp. 33-42, 2008.

[83] J. Dannull, Z. Su, D. Rizzieri, et al., "Enhancement of vaccine-mediated antitumor immunity in cancer patients after depletion of regulatory T cells," Journal of Clinical Investigation, vol. 115, no. 12, pp. 3623-3633, 2005.

[84] O. P. Kristiansen, Z. M. Larsen, and F. Pociot, "CTLA-4 in autoimmune diseases-a general susceptibility gene to autoimmunity?" Genes and Immunity, vol. 1, no. 3, pp. 170-184, 2000.

[85] E. A. Tivol, F. Borriello, A. N. Schweitzer, W. P. Lynch, J. A. Bluestone, and A. H. Sharpe, "Loss of CTLA-4 leads to massive lymphoproliferation and fatal multiorgan tissue destruction, revealing a critical negative regulatory role of CTLA-4," Immunity, vol. 3, no. 5, pp. 541-547, 1995.
[86] P. Waterhouse, J. M. Penninger, E. Timms, et al., "Lymphoproliferative disorders with early lethality in mice deficient in Ctla-4," Science, vol. 270, no. 5238, pp. 985-988, 1995.

[87] A. Ribas, L. H. Camacho, G. Lopez-Berestein, et al., "Antitumor activity in melanoma and anti-self responses in a phase I trial with the anti-cytotoxic T lymphocyte-associated antigen 4 monoclonal antibody CP-675,206," Journal of Clinical Oncology, vol. 23, no. 35, pp. 8968-8977, 2005.

[88] R. P. Sutmuller, L. M. van Duivenvoorde, E. van Elsas, et al., "Synergism of cytotoxic T lymphocyte-associated antigen 4 blockade and depletion of $\mathrm{CD} 25^{+}$regulatory $\mathrm{T}$ cells in antitumor therapy reveals alternative pathways for suppression of autoreactive cytotoxic T lymphocyte responses," The Journal of Experimental Medicine, vol. 194, no. 6, pp. 823-832, 2001.

[89] J. Vollmer, R. Weeratna, P. Payette, et al., "Characterization of three CpG oligodeoxynucleotide classes with distinct immunostimulatory activities," European Journal of Immunology, vol. 34, no. 1, pp. 251-262, 2004.

[90] J. Vollmer and A. M. Krieg, "Immunotherapeutic applications of CpG oligodeoxynucleotide TLR9 agonists," Advanced Drug Delivery Reviews, vol. 61, no. 3, pp. 195-204, 2009.

[91] B. G. Molenkamp, B. J. R. Sluijter, P. A. M. Van Leeuwen, et al., "Local administration of PF-3512676 CpG-B instigates tumor-specific CD8 ${ }^{+}$T-cell reactivity in melanoma patients," Clinical Cancer Research, vol. 14, no. 14, pp. 4532-4542, 2008.

[92] M. M. Hipp, N. Hilf, S. Walter, et al., "Sorafenib, but not sunitinib, affects function of dendritic cells and induction of primary immune responses," Blood, vol. 111, no. 12, pp. 5610-5620, 2008.

[93] S. K. Nair, M. Morse, D. Boczkowski, et al., "Induction of tumor-specific cytotoxic T lymphocytes in cancer patients by autologous tumor RNA-transfected dendritic cells," Annals of Surgery, vol. 235, no. 4, pp. 540-549, 2002.

[94] M. A. Morse, S. K. Nair, P. J. Mosca, et al., "Immunotherapy with autologous, human dendritic cells transfected with carcinoembryonic antigen mRNA," Cancer Investigation, vol. 21, no. 3, pp. 341-349, 2003.

[95] D. A. Caruso, L. M. Orme, A. M. Neale, et al., "Results of a phase 1 study utilizing monocyte-derived dendritic cells pulsed with tumor RNA in children and young adults with brain cancer," Neuro-Oncology, vol. 6, no. 3, pp. 236-246, 2004.

[96] D. A. Caruso, L. M. Orme, G. M. Amor, et al., "Results of a phase I study utilizing monocyte-derived dendritic cells pulsed with tumor RNA in children with stage 4 neuroblastoma," Cancer, vol. 103, no. 6, pp. 1280-1291, 2005.

[97] Z. Su, J. Dannull, B. K. Yang, et al., "Telomerase mRNAtransfected dendritic cells stimulate antigen-specific $\mathrm{CD}^{+}$ and $\mathrm{CD} 4^{+} \mathrm{T}$ cell responses in patients with metastatic prostate cancer," Journal of Immunology, vol. 174, no. 6, pp. 3798-3807, 2005.

[98] L. J. Mu, J. A. Kyte, G. Kvalheim, et al., "Immunotherapy with allotumour mRNA-transfected dendritic cells in androgenresistant prostate cancer patients," British Journal of Cancer, vol. 93, no. 7, pp. 749-756, 2005.

[99] B. Weide, S. Pascolo, B. Scheel, et al., "Direct injection of protamine-protected mRNA: results of a phase $1 / 2$ vaccination trial in metastatic melanoma patients," Journal of Immunotherapy, vol. 32, no. 5, pp. 498-507, 2009. 


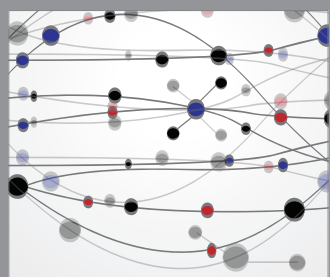

The Scientific World Journal
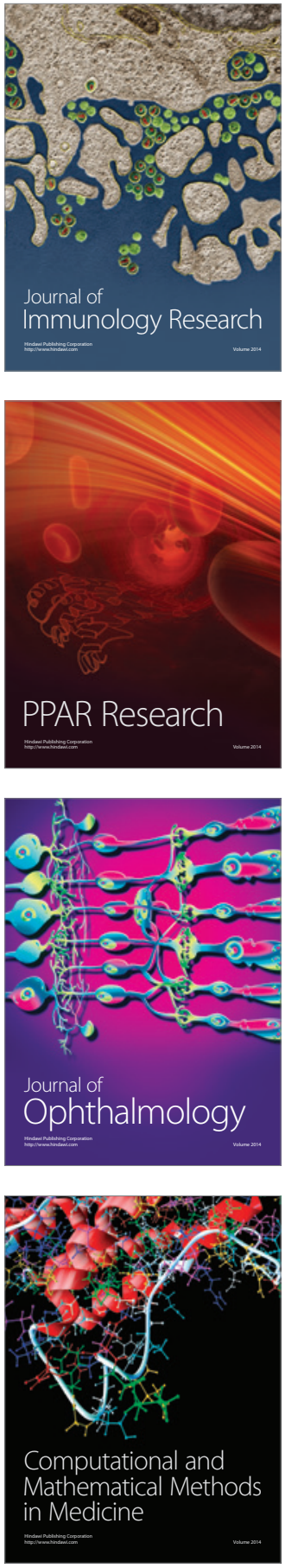

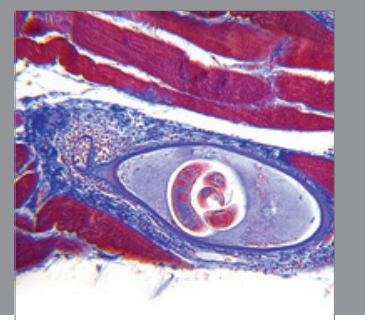

Gastroenterology

Research and Practice
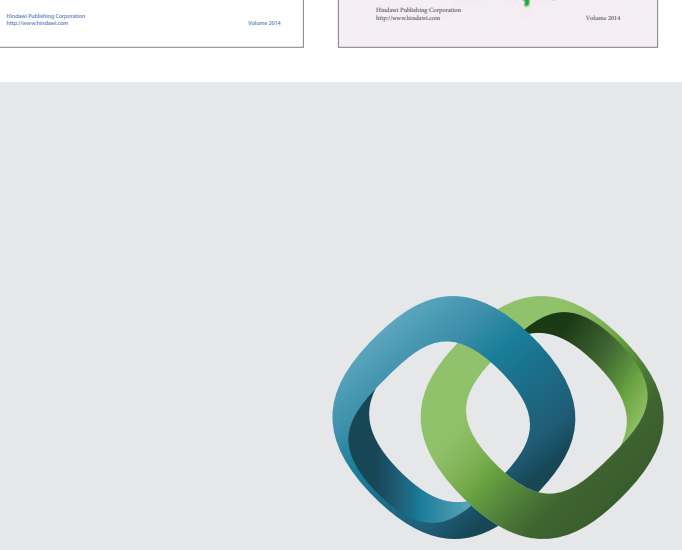

\section{Hindawi}

Submit your manuscripts at

http://www.hindawi.com
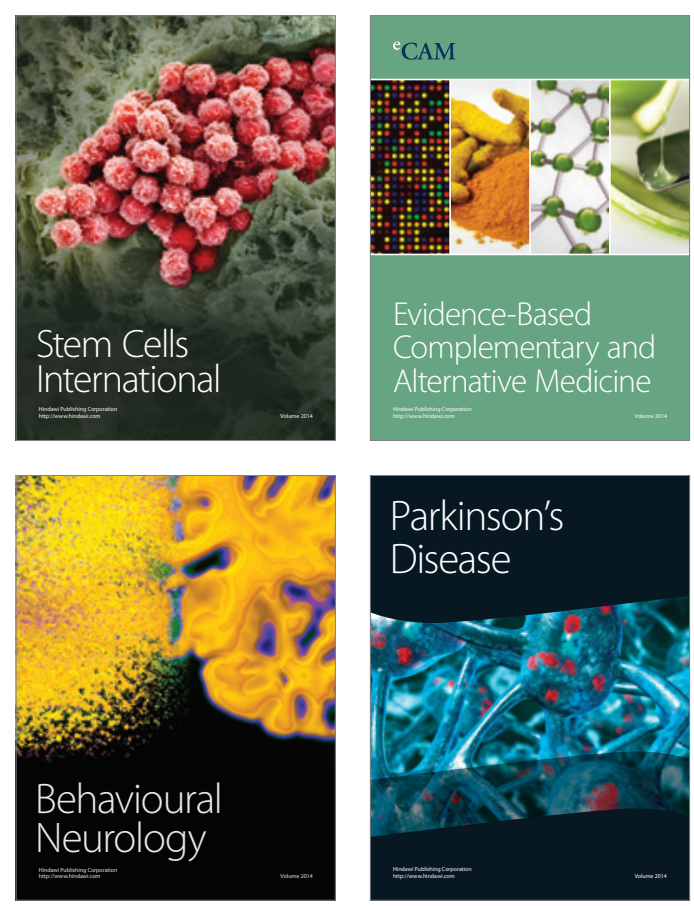

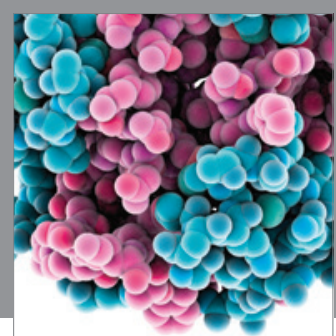

Journal of
Diabetes Research

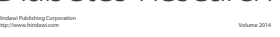

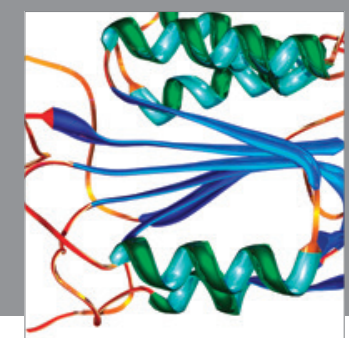

Disease Markers
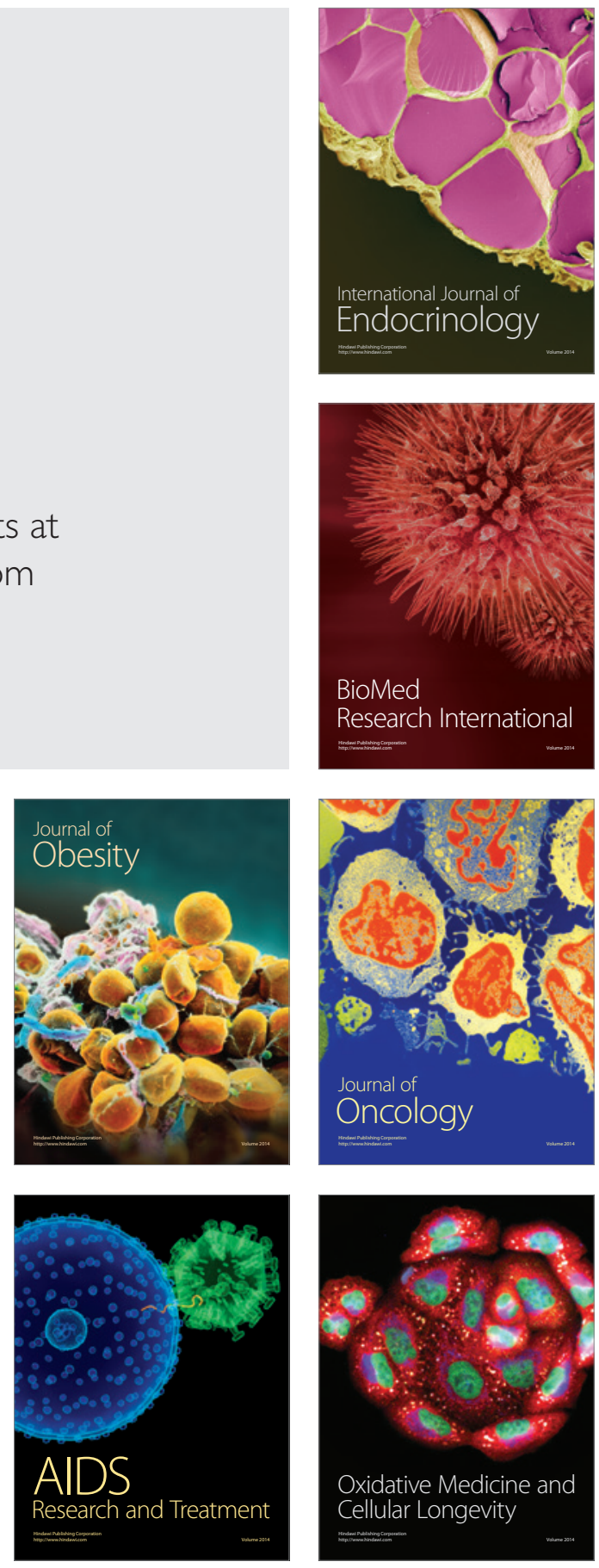